\title{
ARTIKELEN
}

\section{Witwassen als bedrijfsmatige activiteit: de verborgen netwerken van witwassers}

\author{
Jo-Anne Kramer, Arjan Blokland \& Melvin Soudijn
}

De Financial Action Task Force (FATF) stelt dat witwassers groepsgewijs kunnen opereren in professionele witwasnetwerken. Professioneel verwijst daarbij naar het tegen vergoeding leveren van diensten op het gebied van witwassen, en netwerken naar het onderling uitbesteden of gebruik maken van de benodigde expertise. Of zulke witwasnetwerken ook in Nederland opereren, is uit het FATF-rapport niet op te maken. In dit artikel wordt daarom gekeken in hoeverre professionele witwassers in Nederland netwerken vormen en in welke mate zij bedrijfsmatig te werk gaan. Bedrijfsmatigheid is hierbij vertaald als betrokkenheid bij meerdere zaken, aantal terugkerende contacten en afwezigheid van familiale relaties. Gebruik makend van politieregistraties zijn daartoe de contacten van 236 professionele witwassers geanalyseerd. Op basis van de resultaten van deze analyses kan worden geconcludeerd dat ook in Nederland professionele witwasnetwerken actief zijn. Binnen de groep professionele witwassers zijn verder verschillen in de mate van bedrijfsmatigheid te onderkennen. Een kanttekening is wel dat de geanalyseerde politieregistraties hoofzakelijk drugsdelicten betreffen. Het blijft daarmee onbekend in hoeverre er bij andere typen delicten (zoals bijvoorbeeld fraude) sprake is van vergelijkbare witwasnetwerken.

\section{Inleiding}

In Nederland zijn diverse instanties en afdelingen betrokken bij de bestrijding van witwassen. Dit wordt ook wel aangeduid als het 'handhavingsnetwerk (anti)witwassen' (Van der Knoop \& Rollingswier, 2015; Unger e.a., 2018). Dit netwerk betreft een dicht woud aan overlegstructuren en samenwerkingsverbanden van betrokken organisaties, zoals bijvoorbeeld het Anti Money Laundering Centre (AMLC), het Financieel Expertise Centrum (FEC), het voormalige Flexibel Intelligence en Expertise Team Financieel-economische criminaliteit (FIET Finec), infobox Crimineel en Onverklaarbaar Vermogen (iCOV) en het Signalenoverleg Witwassen (SOW). Ook internationaal wordt er in de bestrijding van witwassen gezamenlijk opgetrokken en zijn hiervoor verschillende werkgroepen en platformen opgericht. Te denken valt aan bijvoorbeeld werkgroepen binnen Europol en Interpol, de Egmont Group en Financial Intelligence Units.

Het bekendste samenwerkingsverband op het gebied van de bestrijding van witwassen is misschien wel de Financial Action Task Force (FATF). Deze intergouvernementele organisatie werd in 1989 door de G7 opgericht om antiwitwasbeleid te ontwikkelen. Dit heeft vorm gekregen in een aantal gezaghebbende aan- 
bevelingen (recommendations), die internationaal zijn overgenomen. Daarnaast publiceert de FATF rapporten over bepaalde fenomenen die specifiek aandacht behoeven. Deze rapporten komen in projectgroepen tot stand waarbij deelnemende landen verzocht wordt om informatie in te sturen of gezamenlijk te analyseren. Zo is in 2018 een rapport getiteld 'Professional money laundering' verschenen (FATF, 2018). Daarin worden, extreem kort samengevat, twee zaken gesignaleerd. Ten eerste wordt ingegaan op het fenomeen van professionele witwassers, personen die tegen vergoeding crimineel geld voor derden witwassen. $\mathrm{Zij}$ zijn doorgaans niet bij het gronddelict zelf betrokken, maar worden speciaal voor het witwassen ingehuurd. Daarbij wordt ook opgemerkt dat professioneel zich niet beperkt tot bepaalde beschermde beroepen, zoals advocaten of notarissen, of wettelijk erkende kantoren in de trustsector. Het FATF-rapport heeft het bijvoorbeeld ook over ondergrondse bankiers of belastingadviseurs zonder vaste praktijk. Ten tweede wordt aangegeven dat zulke witwassers in gezamenlijkheid aan projecten kunnen werken. Er is dan sprake van professional money laundering networks. ${ }^{1}$

Het bestaan van professionele witwassers is op zichzelf geen nieuw inzicht. In diverse wetenschappelijke publicaties wordt al jaren aangegeven dat er personen bestaan die zich lenen voor of gespecialiseerd hebben in witwassen. Een historisch voorbeeld is Meyer Lansky (1902-1983), die voor de Amerikaanse maffia in de jaren 30 al crimineel geld in legale activiteiten wist te verhullen (Lacey, 1991). ${ }^{2}$ Ook in Nederland is al meerdere malen op het bestaan van professionele witwassers gewezen (Kleemans e.a., 2002; Kruisbergen e.a., 2012; 2019).

Over de mogelijke samenwerking tussen witwassers in Nederland is echter minder informatie te vinden. Voor bepaalde subgroepen zoals hawalabankiers wordt opgemerkt dat zij vanwege gedeelde etnische of familiale achtergrond voor elkaar zullen inspringen of samenwerken wanneer het zo uitkomt (Passas, 1999; Siegel \& Van de Bunt, 2014). Maar in hoeverre de Nederlandse markt voor witwassen in brede zin met elkaar verbonden is, is niet bekend. Om deze reden is de centrale onderzoeksvraag van dit artikel: bestaan er in Nederland professionele witwasnetwerken, en zo ja, in hoeverre zijn er aanwijzingen van bedrijfsmatig handelen binnen deze netwerken? Voor het beantwoorden van deze vraag wordt gebruik gemaakt van kwantitatieve politiegegevens, die met behulp van sociale netwerkanalyse worden geïnterpreteerd.

Dit artikel is als volgt opgebouwd. In de volgende paragraaf wordt eerst de aanpak van witwassen in Nederland kort besproken. Daarbij wordt ook ingegaan op een mogelijk onderscheid in de professionaliteit van witwassen. In de paragraaf 'Data en methode' wordt uitleg gegeven over de gebruikte politieregistratiegegevens, operationalisaties van belangrijke begrippen en de gehanteerde analysemethoden. Vervolgens komen de resultaten van de analyses aan bod, die uiteindelijk in de

1 Het EU Drug Markets Report 2019 (EMCDDA/Europol, 2019) spreekt zelfs over witwassyndicaten. Hoewel de term het ergste doet vermoeden, blijkt het gewoon om professionele witwasnetwerken te gaan, zoals deze door het FATF (2018) zijn beschreven.

2 Al was Lansky zelf ook betrokken bij onderliggende criminele activiteiten. 
paragraaf 'Discussie' van nader commentaar worden voorzien. Hier worden ook enkele kanttekeningen bij het huidige onderzoek geplaatst.

\section{Achtergrond}

In Nederland is het witwassen van crimineel vermogen sinds 2001 strafbaar gesteld. ${ }^{3}$ Volgens de memorie van toelichting is een belangrijk doel van deze strafbaarstelling het weren van crimineel geld uit de legale economie. ${ }^{4}$ Maar ook buiten de legale economie is het antiwitwasartikel van toepassing. Iemand kan voor witwassen worden vervolgd als hij/zij geld (of voorwerpen) uit een misdrijf afkomstig ontvangt, bezit of gebruikt, terwijl hij/zij kennis had, of redelijkerwijze had kunnen vermoeden, dat het uit een misdrijf afkomstig is. In 2017 werden met de invoering van de Wijzigingswet eenvoudig witwassen ook het verwerven en voorhanden hebben van voorwerpen onmiddellijk afkomstig uit zelf gepleegde misdrijven afzonderlijk als 'eenvoudig witwassen' strafbaar gesteld. ${ }^{5}$ Het strafrecht is bovendien niet het enige middel dat wordt ingezet om witwassen tegen te gaan. Op basis van de Wet ter voorkoming van witwassen en financieren van terrorisme (Wwft) zijn verschillende instanties en personen, zoals banken, notarissen en accountants, verplicht om verdachte transacties aan de bevoegde instanties te melden.

Het gevolg van deze antiwitwaswetgeving en -bepalingen is dat er drempels zijn opgeworpen om crimineel geld, direct of indirect, in de legale economie te kunnen besteden. Waar die drempels precies liggen, is moeilijk aan te geven. Kruimeldieven en hosselaars bijvoorbeeld zullen hiervan weinig hinder ondervinden. Hun criminele activiteiten leveren zo weinig winst op dat zij die opbrengsten zonder problemen in hun dagelijkse uitgaven kunnen opnemen. Denk bijvoorbeeld aan het contant betalen van boodschappen of het geven van een rondje in de stamkroeg (waar sowieso geen vragen worden gesteld). Aan de andere kant van het spectrum bevinden zich de criminele grootverdieners. Zij genereren te veel crimineel geld om dit in hun dagelijkse uitgaven te kunnen verhullen. De aanschaf van bijvoorbeeld een dure auto of vastgoed is door de vele antiwitwasbepalingen niet zomaar met contant geld te voldoen. Publiek-private partijen zijn alert op een eventuele criminele herkomst van het geld en moeten bij vermoedens van witwassen hiervan een melding doen bij de bevoegde autoriteiten. Hierdoor bestaat er een reële kans dat tegen de crimineel een financieel opsporingsonderzoek wordt gestart. Veel hangt dus af van de vraag hoe financieel kundig de crimineel zelf is. Een fraudeur kan bijvoorbeeld best een ingewikkelde constructie met

3 Witwassen is in het Wetboek van Strafrecht strafbaar gesteld in de artikelen 420bis (opzettelijk witwassen), 420ter (gewoonte witwassen) en 420quarter (schuld witwassen).

4 Wijziging van het Wetboek van Strafrecht en enkele andere wetten in verband met de strafbaarstelling van het witwassen van opbrengsten van misdrijven, Kamerstukken II 1999/2000, 27159, nr. 3 (MvT).

5 De Hoge Raad had eerder de reikwijdte van de voor 2017 geldende antiwitwasbepalingen beperkt om automatische dubbele strafbaarstelling van plegers van het gronddelict te voorkomen, zie $\mathrm{HR}$ 26 oktober 2010, ECLI:NL:HR:2010:BM4440. 
een kerstboom aan bedrijven opzetten om zijn criminele geld een schijn van legale herkomst te geven. Maar een groothandelaar in drugs ontbreekt het wellicht aan de financiële skills om zoiets voor elkaar te krijgen. In plaats van self-laundering (Malm \& Bichler, 2013) zal hij financiële expertise moeten inhuren om zijn zwarte geld wit te wassen. Dergelijke experts staan bekend als professionele witwassers (FATF, 2018; Malm \& Bichler, 2013), enablers (Middleton \& Levi, 2015) of financieel facilitators (Soudijn, 2014). Subtiel verschil zit soms in de afbakening. Malm en Bichler (2013) beschrijven professionele witwassers als personen die bij het witwassen (de kennis uit) hun legale beroep gebruiken. Soudijn (2014) liet echter zien dat er ook personen zonder een legale beroepsfunctie of -achtergrond bij professionele witwaspraktijken zijn betrokken. Te denken valt aan ondergrondse bankiers of financieel adviseurs zonder legale praktijk.

De discussie over het wel of niet gehad hebben van professionele training valt te omzeilen door te denken in termen van 'faciliteren'. Facilitators zijn personen die een oplossing kunnen bieden voor bepaalde problemen waar criminelen tegenaan lopen. Ze leveren daardoor essentiële diensten voor de uitvoering van een misdrijf (Kleemans e.a., 2002). Een financial facilitator is dus iedereen die een crimineel terzijde staat op het gebied van witwassen en daarbij een sleutelrol vervult (Soudijn, 2017). Deze opvatting wordt ook door de FATF (2018) gedeeld. De FATF voegt daaraan toe dat professionele witwassers ook in netwerken kunnen opereren. Deze worden door hen professional money laundering networks genoemd.

Voor het bestaan van witwasnetwerken kunnen vanuit de literatuur twee verklaringen worden aangedragen. Ten eerste is er bij wereldwijd opererende systemen of organisaties, zoals ondergronds bankieren, soms sprake van extended families of gedeelde herkomstgebieden. Niet alleen is men door een gedeelde familiale of etnische achtergrond eerder bereid voor elkaar in te springen, ook is het juist de samenwerking tussen partijen die maakt dat het netwerk zo effectief geld kan verplaatsen (Passas, 1999; Siegel \& Van de Bunt, 2014).

Een tweede verklaring voor het bestaan van witwasnetwerken is te vinden in specialisme. In de literatuur (en praktijk) van de misdaadpreventie is door middel van crime scripting aangetoond dat criminele activiteiten vaak in stukken kunnen worden geknipt (Cornish, 1994; Leclerc, 2008). Een criminele activiteit als seksuele uitbuiting wordt dan niet langer meer opgevat als het enkele criminele feit mensenhandel, maar eerder als een keten van handelingen die dit feit mogelijk maken. Binnen die keten kunnen verschillende personen samenwerken met elk een eigen specialisme. Te denken valt bijvoorbeeld aan iemand voor het regelen van valse papieren, het smokkelen van de personen over de landsgrenzen, het regelen van onderdak, het regelen van een werkplek, het vervoeren naar die werkplek, het toezicht op de gesmokkelde personen en voor het beheer van het (door de gesmokkelde personen verdiende) geld (Savona e.a., 2014). Voor ingewikkelde of grootschalige vormen van witwassen kan evenzogoed een crime script worden opgesteld en kunnen verschillende handelingen en actoren worden onderscheiden (Gilmour, 2014). Uit de Panama Papers is bijvoorbeeld duidelijk geworden dat diverse kleine financieel adviesbureautjes als feeders voor grotere bankpartijen werkten door tegen commissie klanten aan te brengen (zie ook Obermayer \& 
Obermaier, 2016). Die klanten werden vervolgens doorgesluisd naar trustkantoren die voor hen op de Bahama's constructies opzetten. Daar waren vervolgens weer personen bij aanwezig die zich tegen vergoeding als nominee en tekenbevoegd opwierpen.

Hoewel het bestaan van witwasnetwerken niet onbekend is, zijn deze in sociale netwerkstudies nog niet apart belicht. Sterker nog, witwassers worden in sociale netwerkanalyse op het gebied van (georganiseerde) criminaliteit vaak alleen als een los contact van de hoofdverdachten opgevoerd (Malm \& Bichler, 2013; Morselli \& Giguere, 2006). Dat komt vermoedelijk doordat dergelijke studies vaak slechts een of enkele zaaksdossiers tot hun beschikking hebben, waardoor achterliggende netwerken onderbelicht blijven. Het is daarom van belang de focus apart op witwassers te leggen om hun onderlinge verbanden bloot te kunnen leggen. In de huidige studie gaan we op basis van door de politie geregistreerde contacten van een steekproef van professionele witwassers na in welke mate zij onderling netwerken vormen en in welke mate het handelen van deze professionele witwassers als bedrijfsmatig kan worden gekarakteriseerd.

\section{Data en methode}

\section{Steekproef}

In dit artikel sluiten we aan bij de definitie van de FATF en anderen (FAFT, 2018; Soudijn, 2017) en beschouwen we iemand als een professionele witwasser als hij of zij essentiële financiële diensten verleent bij het witwassen van door anderen crimineel verdiend geld, ongeacht de formele beroepsachtergrond van deze persoon. Professionele witwassers staan vaak ver af van de initiële criminele activiteit, zoals de handel in drugs. Daardoor worden zij doorgaans niet direct als verdachte aangemerkt als het onderzoek zich op het gronddelict richt (FATF, 2018). Vaak is een apart financieel opsporingsonderzoek nodig om witwassers aan te pakken, iets wat door capaciteitsgebrek niet altijd plaatsvindt.

Witwassers worden zodoende lang niet altijd vervolgd. Dat wil echter niet zeggen dat zij daarom ook altijd onbekenden van de politie zijn. Tijdens het opsporingsonderzoek naar de hoofdverdachten van een misdrijf worden namelijk wel alle contacten van deze verdachten geregistreerd (althans, voor zover deze tijdens het onderzoek in beeld zijn gekomen en er voldoende recherchecapaciteit is om deze te verwerken). Als er contact met een witwasser heeft plaatsgevonden, bijvoorbeeld een telefoongesprek of een fysieke ontmoeting in een restaurant, kan deze contactinformatie in de politiesystemen worden geregistreerd.

Voor de dataverzameling in dit artikel is daarom als volgt te werk gegaan. Na toestemming van het bevoegd gezag is allereerst bij de voormalige afdeling FIET Finec van de Landelijke Eenheid (LE) gevraagd om professionele witwassers voor een netwerkanalyse in kaart te brengen. Op basis van ervaring en dossierkennis van de teamleider en analisten van deze afdeling leverde dit een bestand op met 
de namen van 302 professionele witwassers. ${ }^{6}$ Deze namen zijn vervolgens uitgezet bij de afdeling Business Intelligence and Competence Center (BICC) van de LE met het verzoek deze te koppelen aan hun contactregistraties, oftewel de personen met wie een of andere vorm van contact is vastgesteld. BICC heeft daartoe de personen gematcht aan hun registraties in Summ-IT, waar ook de Basisvoorziening Handhaving (BVH) in is opgenomen. In de BVH staat informatie over strafbare feiten tot vijf jaar terug. Het is een systeem dat voornamelijk handhavingsgegevens bevat, zoals meldingen van incidenten, overtredingen en misdrijven (Bijleveld, 2018, 191). Summ-IT is een systeem dat wordt gebruikt door de recherche en waarin relatief grote zaken geregistreerd staan tot tien jaar terug. Het systeem bevat vooral opsporingsinformatie (Bijleveld, 2018, 191). De BVH en Summ-IT zijn beide landelijke systemen.

De dataverzameling op basis van deze systemen vond plaats van 23 november 2018 tot en met 15 januari 2019. De hier gebruikte gegevens hebben betrekking op alle opsporingsonderzoeken die tussen januari 2008 en december 2018 in ten minste één van beide systemen werden geregistreerd. Dit leverde een bestand op met informatie over 236 professionele witwassers (78,1 procent van de initiële steekproef), de opsporingsonderzoeken waarin zij als verdachte zijn aangemerkt, en de relaties van die professionele witwassers met andere betrokkenen in die zaken.

\section{Contactregistraties}

Het databestand bevat in totaal gegevens over 656 verschillende opsporingsonderzoeken, 3.220 verschillende contactpersonen en 4.830 verschillende contactregistraties. Voorafgaand aan de daadwerkelijke analyses werden zowel de namen van de opsporingsonderzoeken als de namen van de betrokken witwassers en hun contacten gepseudonimiseerd, zodat de structuur van de data behouden bleef, maar de betreffende informatie niet meer herleidbaar was tot individuele zaken of personen.

Het databestand bevat per contactregistratie ook gegevens over de aard van de relatie. In de politieregistraties die ons ter beschikking werden gesteld, werden 200 verschillende categorieën gebruikt om de aard van de relatie aan te duiden. ${ }^{7}$ Voor analysedoeleinden is dit aantal door ons teruggebracht tot acht, waarbij functioneel equivalente categorieën zijn samengevoegd. Zo werden bijvoorbeeld relaties als broer, zus, vader en moeder samengebracht onder de overkoepelende categorie 'familie'.

De beschikbare gegevens over de aard van de relatie zijn voor de meeste relaties overigens niet erg informatief. In 54,9 procent van de gevallen is de aard van de relaties tussen een witwasser en een andere betrokkene in de zaak niet nader

6 De politiemedewerkers van de afdeling FIET Finec hebben daarbij de FATF-omschrijving voor professioneel witwasser gehanteerd. Ter controle heeft de derde auteur, die tevens werkzaam was bij FIET Finec, de aldus verzamelde groep witwassers handmatig gecontroleerd door de achterliggende informatie door te nemen.

$7 \quad$ Hierbij is vaak sprake van overlap. Zo worden vriendinnen van criminelen doorgaans aangeduid als 'vriendin' of 'partner', maar we zijn ook registraties als 'bijvrouw', 'concubine' en het curieuze 'concubinaris' tegengekomen. 


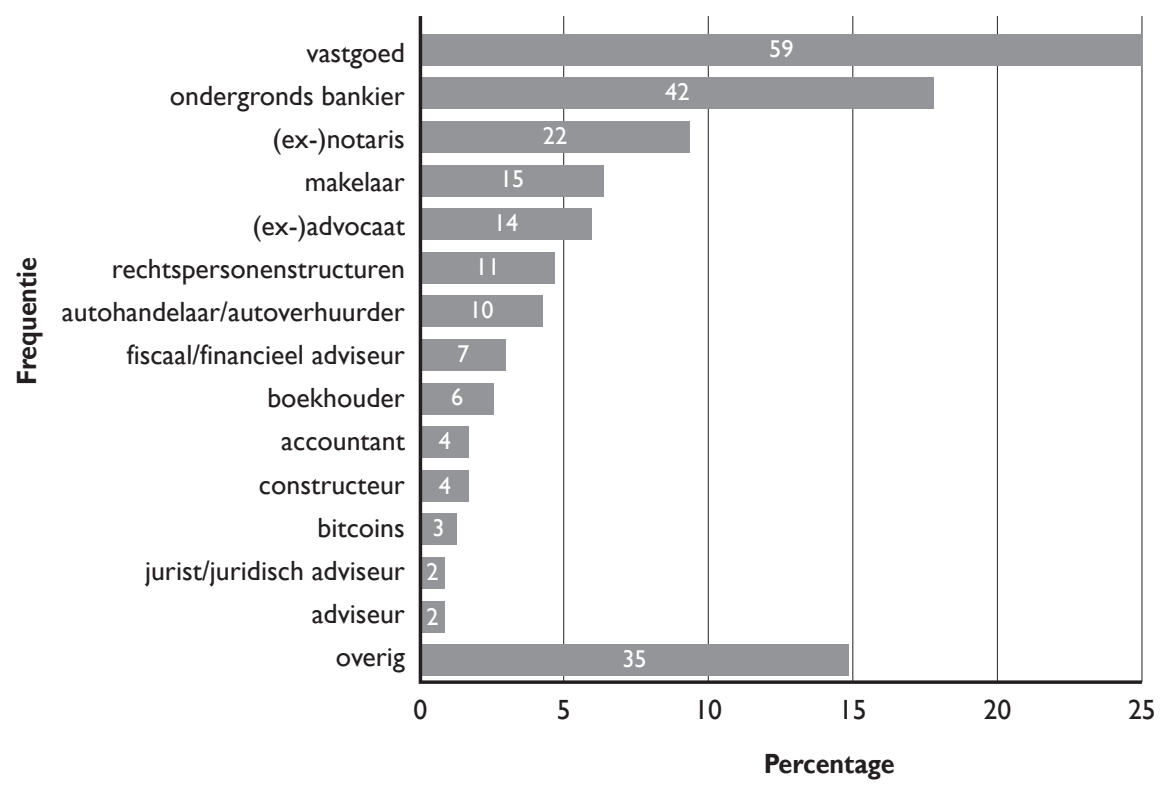

Figuur 1 Procentuele verdeling van de professionele witwassers over de expertisegroepen (absolute aantallen weergegeven in de balk) $(N=236)$ Van één witwasser is geen expertisegroep bekend.

gespecificeerd. ${ }^{8}$ In de gevallen waarin de aard van een relatie wel is gespecificeerd, betreft het een familiale (19,4 procent), zakelijke (16,1 procent), sociale (3,2 procent), criminele (2,7 procent) of financiële relatie (1,7 procent), of heeft de ene persoon verklaard over de ander, op grond waarvan het bestaan van een relatie tussen de twee personen kon worden aangenomen (1,7 procent). Van alle relaties werd tot slot 0,3 procent gecategoriseerd als 'overig'.

Geregistreerde contacten tussen witwassers en andere personen binnen het opsporingsonderzoek en geregistreerde contacten tussen witwassers onderling worden opgevat als proxy voor het bestaan van een samenwerkingsrelatie tussen deze personen.

\section{Expertisegroepen}

Het bestand bevat ook gegevens over de expertise van iedere witwasser (bijvoorbeeld boekhouder, autohandelaar of ondergronds bankier). Evenals bij de aard van de relaties het geval is, bevatten de politieregistraties verschillende, vaak elkaar overlappende termen om de expertise van de witwasser aan te duiden. De 48 verschillende aanduidingen voor hun expertise zijn uiteindelijk teruggebracht tot vijftien verschillende categorieën (zie figuur 1).

8 Bright e.a. (2015) maakten voor hun onderzoek naar netwerken binnen de drugshandel gebruik van dossiers van de openbaar aanklager en zij liepen tegen hetzelfde probleem aan. In hun onderzoek was in 69 procent van de gevallen de aard van een relatie onbekend. 
De meeste witwassers vallen in de expertisegroep 'vastgoed' en 'ondergronds bankier'. De groep ondergrondse bankiers blijkt voor 92,9 procent uit hawalabankiers te bestaan, de overigen verzorgen contante geldsmokkel naar Zuid-Amerika. ${ }^{9}$ Sommige expertisegroepen blijken weinig voor te komen, maar konden niet zonder verlies van informatie worden samengevoegd omdat ze hiervoor te verschillend waren.

De onderzoeksobjecten van de huidige studie zijn dus professionele witwassers die, blijkens politiegegevens, in contact hebben gestaan met criminele subjecten. De professionele witwassers zijn in ten minste één opsporingsonderzoek officieel als verdachte aangemerkt. Het komt voor dat zij in andere zaken slechts als contact van een verdachte witwasser zijn aangemerkt.

\section{Sociale netwerkanalyse}

Om de onderlinge contacten tussen professionele witwassers in kaart te brengen en te analyseren maken we gebruik van methoden en technieken uit de sociale netwerkanalyse (SNA) (Morselli, 2014). In SNA worden personen aangeduid als nodes en relaties tussen die personen als edges. De bestaande relaties tussen een verzameling personen kunnen vervolgens op twee niveaus worden geanalyseerd, op het niveau van het totale netwerk en op het niveau van individuele nodes binnen dit netwerk. Op netwerkniveau geven bijvoorbeeld het totaal aantal nodes, het aantal componenten en de mate waarin het netwerk gecentraliseerd is, belangrijke informatie over de structuur van het totale netwerk. Op individueel niveau kan vervolgens worden nagegaan wat bijvoorbeeld het aantal relaties is dat een node in het netwerk heeft (degree) en in welke mate de positie van een node in het netwerk samenhangt met individuele kenmerken van die betreffende node (Borgatti e.a., 2013).

De term degree centrality wordt hierbij gebruikt om te verwijzen naar de positie van individuele personen in een netwerk. In het huidige onderzoek verwijst degree naar het aantal andere witwassers met wie een professionele witwasser contact heeft. Centralization wordt gebruikt om een heel netwerk te karakteriseren. Een netwerk is meer gecentraliseerd naarmate personen meer variëren wat betreft hun centraliteitsscores. Degree centralization verwijst hier naar de proportie van het netwerk die direct gekoppeld kan worden aan de witwasser met de hoogste degree centrality-score (Bichler, 2019). ${ }^{10}$ De waarde degree centralization kan variëren van 0 (niet gecentreerd) tot 1 (maximaal gecentreerd).

\section{Kenmerken bedrijfsmatig handelen}

Volgens gangbare definities wordt bedrijfsmatig handelen gekenmerkt door regelmaat, efficiëntie, professionaliteit en het hebben van een winstoogmerk. De voor dit onderzoek beschikbare gegevens geven echter geen informatie over bijvoor-

9 Hawalabankiers verplaatsen geld over het algemeen niet contant maar virtueel. Voor meer informatie, zie bijvoorbeeld Soudijn, 2015; Siegel \& Van de Bunt, 2014; Maimbo, 2003.

10 Degree centralization wordt berekend door de variatie tussen individuele witwassers in het aantal contacten dat zij hebben met andere witwassers te delen door de maximale variatie in het aantal contacten dat mogelijk is gegeven het aantal personen in het netwerk. 
beeld de complexiteit van de witwasconstructie of de hoogte van de ontvangen commissie. Kenmerken van bedrijfsmatig handelen moeten daarom worden afgeleid uit de beschikbare gegevens over professionele witwassers en hun contacten. Malm en Bichler (2013) maken naast self-launderers onderscheid tussen professional money launderers en opportunistic money launderers, waarbij de laatste slechts op incidentele basis geld witwast voor een persoon met wie hij een familiale of sociale band heeft. Regelmaat is een belangrijk kenmerk van bedrijfsmatigheid en onderscheidt volgens Malm en Bichler (2013) professionele van opportunistische witwassers. Hoewel geen onderdeel van de hier gehanteerde definitie van professioneel witwasser, vatten we wanneer witwassers in meerdere onderzoeksdossiers naar voren komen, dit wel op als een belangrijke aanwijzing voor bedrijfsmatig handelen. Ook wanneer witwassers in verschillende zaken contacten hebben met verschillende personen kan dit duiden op bedrijfsmatigheid: dit suggereert immers dat de witwasser werkt voor verschillende criminelen of criminele groepen. Tegelijkertijd kan bedrijfsmatigheid ook worden afgeleid uit het aantal terugkerende contacten. Terugkerende contacten duiden immers op een vaker dan incidenteel contact tussen partijen. Het ontbreken van familiale banden tussen witwassers en hun contacten ten slotte, wordt ook opgevat als een aanwijzing voor bedrijfsmatig handelen.

\section{Resultaten}

\section{Netwerk op basis van contactregistraties}

Om na te gaan of er netwerken van professionele witwassers in Nederland bestaan, hebben we de beschikbare data op twee manieren geanalyseerd: een (restrictieve) versie waarbij pas een (samenwerkings)relatie tussen beide witwassers werd aangenomen als ook daadwerkelijk een contact tussen hen werd geregistreerd, en een (minder restrictieve) versie waarbij al een (samenwerkings)relatie tussen witwassers werd verondersteld, omdat zij beiden in hetzelfde dossier als verdachte werden genoemd. ${ }^{11}$ In beide gevallen gaat het om een undirected netwerk, dat wil zeggen: we weten dat er contact is tussen twee personen, maar niet wie de zender of ontvanger is. De resultaten van de beide sociale netwerkanalyses zijn vermeld in tabel 1 .

Wanneer gekeken wordt naar de relaties (edges) tussen professionele witwassers (nodes) op basis van geregistreerde contacten, dan blijkt dat 130 van de 236 witwassers (55,1 procent) ten minste één keer contact hebben met ten minste één andere witwasser. Van deze 130 witwassers kunnen er 89 (68,5 procent) via hun

11 Bij het netwerk op basis van zaaksdossiers werden vijf zaken slechts deels in de analyse opgenomen en één zaak helemaal niet. Deze zaaksdossiers bleken geen betrekking te hebben op reguliere opsporingsonderzoeken. Uit deze zes zaken werden daarom, voor zover aanwezig, enkel officieel geregistreerde contacten tussen professionele witwassers meegenomen (op dezelfde wijze als in het netwerk op basis van contactregistraties). Dit om te voorkomen dat het aantal relaties tussen professionele witwassers in het netwerk op basis van in dezelfde zaak genoemd worden disproportioneel zou worden beïnvloed door een beperkt aantal 'zaken' waarin veel professionele witwassers genoemd werden. 
Tabel 1 Beschrijving van het sociale netwerk tussen professionele witwassers in 2008-2018 op basis van politieregistraties

\begin{tabular}{lll}
\hline & \multicolumn{2}{c}{ Netwerk op basis van } \\
& Contactregistraties & Vermeld in dezelfde zaak \\
\hline Type netwerk & I-mode & I-mode \\
Aantal nodes & 130 & 202 \\
Aantal edges & 154 & 1.175 \\
Aantal components & $\mathrm{II}$ & $\mathrm{I}$ \\
Grootte van de grootste component & $68,5 \%$ & $100 \%$ \\
Degree centrality & $\mathrm{I}-14$ & $\mathrm{I}-54$ \\
Average degree & 2,37 & $\mathrm{II}, 63$ \\
Degree centralization & 0,09 & $0,2 \mathrm{I}$ \\
\hline
\end{tabular}

contacten met andere witwassers direct of indirect aan elkaar worden verbonden (largest component). Het aantal andere witwassers met wie een witwasser contact heeft (degree centrality), varieert van een tot veertien, met een gemiddelde van 2,37 (average degree). Het aantal contacten met andere witwassers blijkt overigens voor een groot deel van de witwassers beperkt: 42,3 procent van de witwassers die contact hebben met een andere witwasser heeft maar met één andere witwasser contact en negen van de tien hebben met minder dan vijf andere witwassers contact. De beperkte variatie in het aantal onderlinge contacten leidt tot een egaal netwerk zonder duidelijke uitschieters (degree centralization). Bijna de helft (49,2 procent) van de professionele witwassers die contacten heeft met andere witwassers heeft in meerdere zaken contact met dezelfde collega-witwasser. In bijna driekwart (73,4 procent) van die gevallen blijft het bij een herhaald contact met één andere witwasser, maar er is ook een witwasser die met zeven verschillende witwassers herhaald contact heeft.

Het netwerk tussen professionele witwassers op basis van contactregistraties is weergegeven in figuur 2, waarbij de dikte en donkerte van de edges relatief is aan het aantal verschillende zaken waarin witwassers met elkaar contact hebben, en het symbool van de nodes de expertisegroep van de betreffende witwasser weergeeft.

Figuur 2 laat nog eens zien dat het netwerk van witwassers in Nederland voor het grootste deel bestaat uit witwassers die actief zijn in de vastgoedsector. De samenwerking tussen vastgoedhandelaren, makelaars en (ex-)notarissen is niet heel verrassend, omdat voor het passeren van een (ver)koopakte nu eenmaal een notaris nodig is. Wat verder opvalt, is dat vier van de elf components volledig bestaan uit ondergrondse bankiers. Van de 29 ondergrondse bankiers in dit netwerk zijn er slechts vier die samenwerken met een financial facilitator met een andere expertise. 

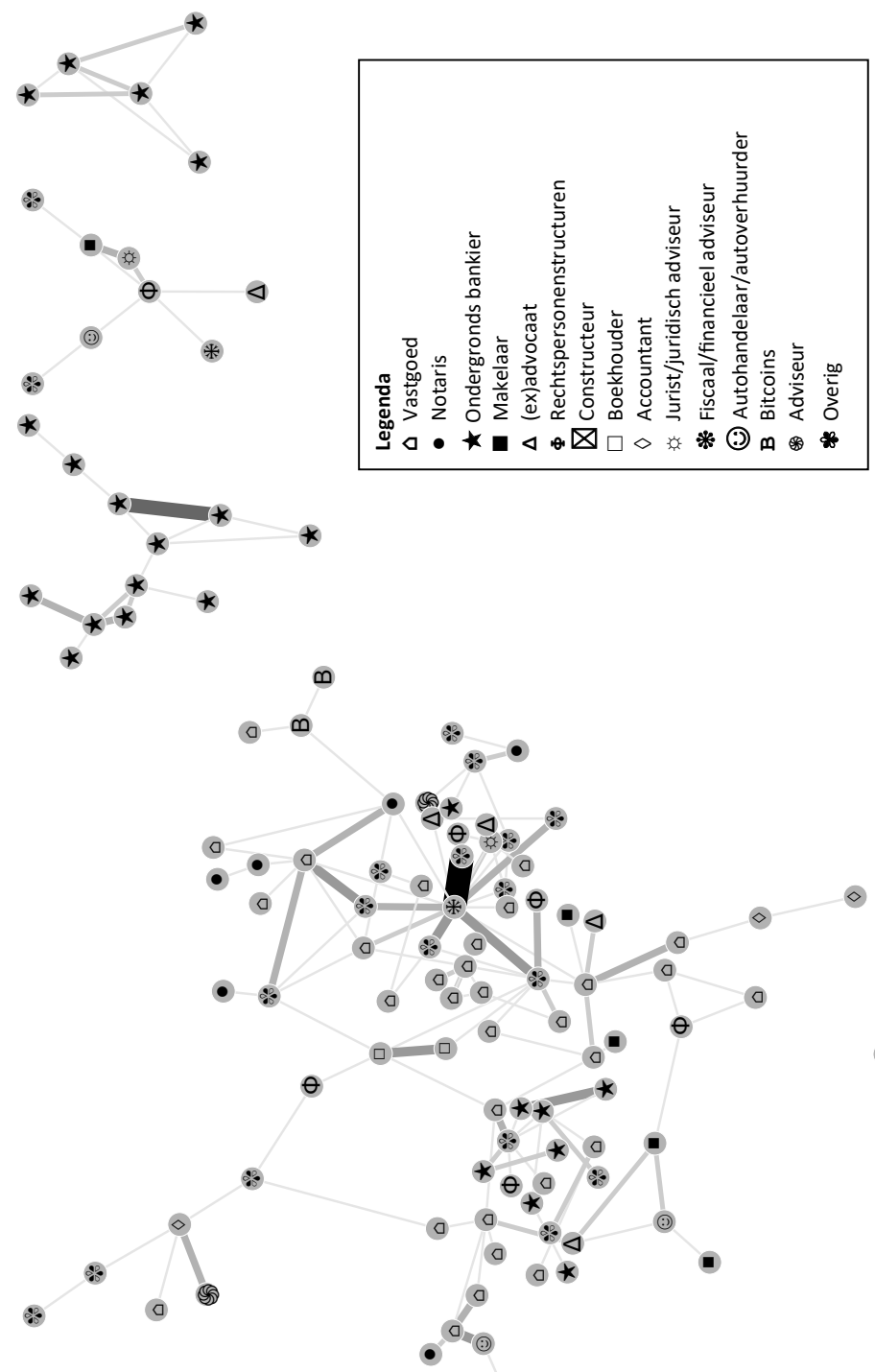

(a)

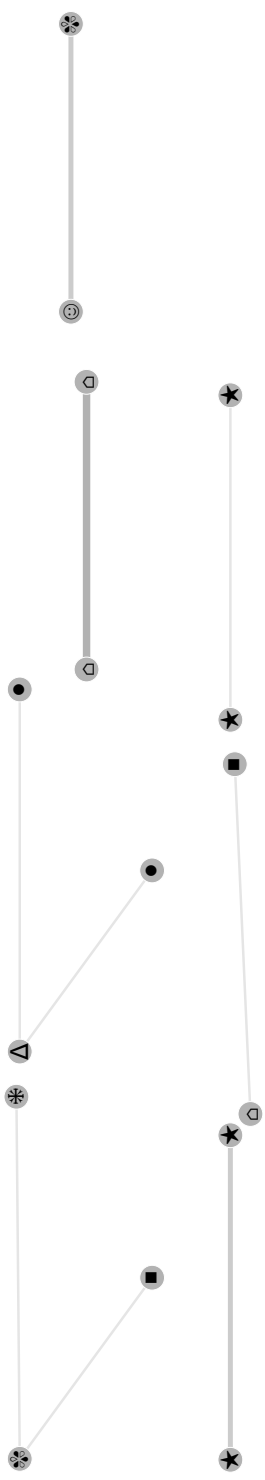

Figuur 2 Witwasnetwerken op basis van contactregistraties $(N=130)$

Netwerk op basis van zaaksdossiers

In een volgende analyse werd opnieuw het netwerk van witwassers in Nederland in kaart gebracht, maar nu op basis van het samen genoemd worden in hetzelfde zaaksdossier. Hoewel het gezamenlijk vermeld staan in een zaaksdossier waarschijnlijk impliceert dat de betrokkenen elkaar kennen en samenwerken, is dit 
niet met zekerheid te zeggen. Een crimineel kan bijvoorbeeld een ondergronds bankier in de hand nemen om zijn geld naar het buitenland te verplaatsen, en een ander om in Nederland een bedrijfsconstructie op te zetten. In zo'n geval hoeven de twee witwassers niets met elkaar van doen te hebben. De spreekwoordelijke lat voor het aannemen van een (samenwerkings)relatie ligt in dit geval dus lager. Toch heeft het in kaart brengen van dit netwerk meerwaarde, omdat wanneer afzonderlijke relaties niet altijd even nauwkeurig nog eens apart door de politie worden geregistreerd, analyses op basis van enkel geregistreerde contacten belangrijke verbanden tussen personen en groepen binnen het netwerk kunnen missen (Rostami \& Mondani, 2015).

Een beschrijving van het netwerk gebaseerd op het samen genoemd worden in een dossier wordt gegeven in kolom 2 van tabel 1 . In een netwerk dat is gebaseerd op het vermeld worden in dezelfde zaak in plaats van op contactregistraties, blijkt dat niet 130 maar 202 van de 236 (85,6 procent) professionele witwassers met elkaar te verbinden zijn. Deze witwassers vormen niet meer meerdere losse subnetwerken (components), maar zijn allen in één groot netwerk met elkaar verbonden. Het aantal witwassers met wie witwassers in dit netwerk in verband kunnen worden gebracht (degree centrality), varieert van 1 tot 54. Iets minder dan de helft van de professionele witwassers ( 43,1 procent) heeft in dit netwerk een relatie met meer dan tien andere witwassers. Gemiddeld hebben witwassers in dit netwerk relaties met 11,6 andere witwassers (average degree). In het netwerk gebaseerd op het samen genoemd worden in een zaaksdossier kan 26,7 procent van de witwassers direct worden gelinkt aan de witwasser met de meeste contacten met andere witwassers. Ook in het netwerk gebaseerd op het samen genoemd worden in dezelfde zaak valt het op dat ondergrondse bankiers veelal met elkaar verbonden zijn. Datzelfde geldt voor vastgoedhandelaren.

\section{Aanwijzingen voor bedrijfsmatig handelen}

Betrokkenheid bij meerdere zaken werd opgevat als een belangrijke aanwijzing voor bedrijfsmatig handelen. Professionele witwassers in onze steekproef blijken gemiddeld bij 5,5 zaken als verdachte betrokken te zijn (verticale lijn in figuur 3). ${ }^{12}$ Figuur 3 laat verder zien dat ongeveer een vijfde (21,2 procent) van de witwassers maar bij één zaak als verdachte is betrokken, terwijl er ook witwassers zijn die bij (veel) meer zaken zijn betrokken.

Een belangrijk onderscheid dat hierbij gemaakt kan worden, is dat tussen witwassers die weleens contact hebben met een andere witwasser $(n=130)$ en witwassers die dat niet hebben $(n=136)$. Witwassers die contact hebben met andere witwassers zijn gemiddeld in 6,9 zaken als verdachte aangemerkt, terwijl witwassers die

12 Het gaat hier om politieregistraties waarin zij op enig moment gedurende een opsporingsonderzoek als mogelijke verdachte werden beschouwd. Dat wil echter niet zeggen dat zij ook daadwerkelijk zijn vervolgd. De vervolging is afhankelijk van keuzes binnen het politieonderzoek en de eventuele zwaarte van de bewijslast. Wij hebben echter geen nadere gegevens over daadwerkelijke vervolging. 


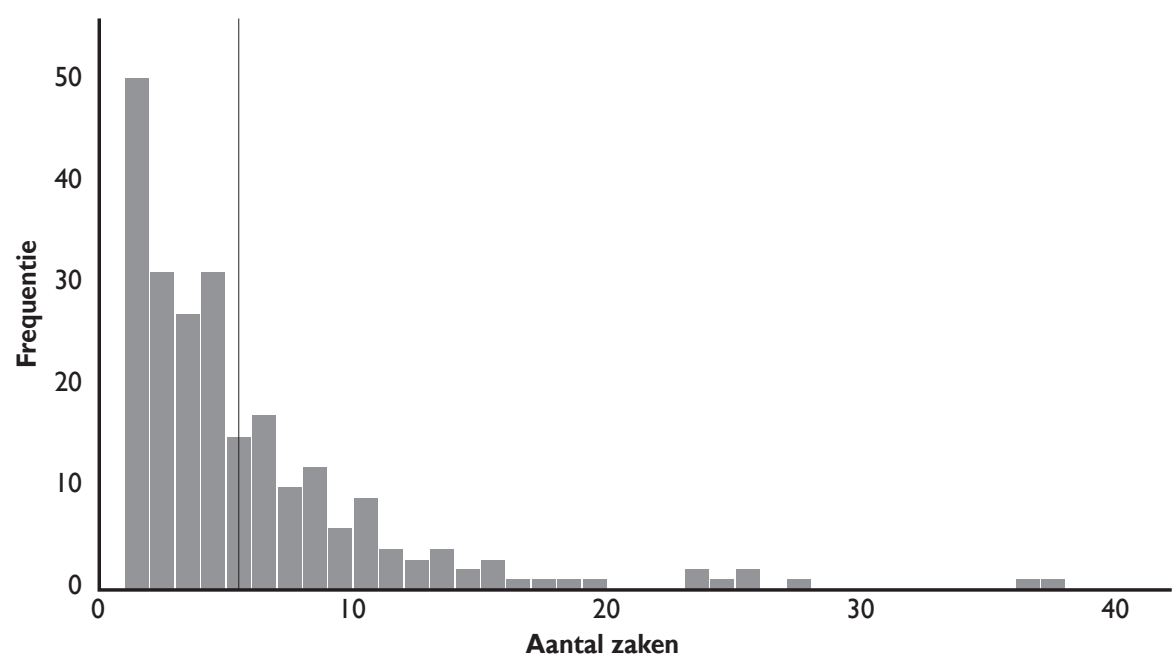

Figuur 3 Aantal zaken waarbij facilitators als verdachte betrokken zijn

$(N=236)$

geen bekende contacten hebben met andere witwassers gemiddeld bij 3,8 zaken als verdachte zijn aangemerkt.

Professionele witwassers blijken gemiddeld met vijftien verschillende betrokkenen contact te hebben. Een grote meerderheid (89,7 procent) heeft met meer dan één betrokkene contact; 22,4 procent heeft contact met meer dan twintig betrokkenen. Eén financial facilitator heeft zelfs contact met 124 verschillende betrokkenen. Witwassers die contact hebben met andere witwassers hebben gemiddeld met negentien verschillende betrokkenen contact, terwijl witwassers die dit niet doen, met gemiddeld 11,0 verschillende betrokkenen contact hebben. Er bestaat overigens een sterk verband tussen het aantal zaken waarbij een witwasser is betrokken en het aantal personen met wie hij of zij contact onderhoudt $(r(236)=0.725, p<0.0001)$, wat betekent dat witwassers die bij meer zaken betrokken zijn over het algemeen ook met meer betrokkenen contact hebben en vice versa.

Van alle onderzochte witwassers heeft een meerderheid (55,9 procent) in meer dan één zaak contact met dezelfde betrokkene. Witwassers die in meerdere zaken contact hebben met dezelfde betrokkenen, hebben met gemiddeld 4,6 betrokkenen herhaald contact. Witwassers die onderling contact hebben, blijken relatief vaker herhaalde contacten te hebben dan witwassers die dit niet doen (respectievelijk 68,5 procent en gemiddeld 5,0 terugkerende contacten en 40,6 procent en gemiddeld 3,8 terugkerende contacten).

Bij een op de vijf (19,4 procent) contacten die voor de professionele witwassers in onze steekproef werden geregistreerd, was er sprake van een familiale relatie, in nog eens 3,2 procent van een sociale relatie. Aangezien het merendeel van de contacten van de professionele witwassers in onze steekproef door de politie niet nader werd gespecificeerd, zijn deze percentages wellicht best op te vatten als een 


\section{Tabel 2}

\section{Correlaties tussen de scores op de (degree-)centraliteitsmaat en verschillende bedrijfsmatigheidskenmerken}

\begin{tabular}{ll}
\hline & Degree centrality \\
\hline Aantal zaken waarbij betrokken & $0.547^{* * *}$ \\
Aantal verschillende contacten & $0.423^{* * *}$ \\
Aantal terugkerende klanten & $0.518^{* * *}$ \\
Percentage familiale relaties & -0.091 \\
\hline
\end{tabular}

*** $\mathrm{p}<.0001 ; * * \mathrm{p}<.01 ; * \mathrm{p}<.05$

ondergrens. De verschillen tussen witwassers die wel en witwassers die geen onderling contact hebben, zijn niet groot. Wat wel opvalt, is dat de relaties van ondergrondse bankiers in 34,4 procent van de gevallen een relatie met een familielid betreffen, terwijl dat percentage bij niet-ondergrondse bankiers slechts 17,1 procent is. Dit verschil is in overeenstemming met bestaand onderzoek, dat aangeeft dat in hawalabankieren familiale relaties een belangrijk element zijn van het vertrouwen dat nodig is om dit systeem te laten functioneren. Overigens zien we dit verschil niet terug als we ons beperken tot relaties tussen witwassers onderling. Niet alleen is er minder vaak sprake van familierelaties tussen witwassers dan tussen witwassers en hun contacten met overige verdachten, hawalabankiers verschillen hierin ook niet noemenswaardig van overige expertisegroepen.

\section{Samenhang netwerkpositie en bedrijfsmatigheid}

Ten slotte is voor het netwerk gebaseerd op geregistreerde contacten tussen witwassers nagegaan in hoeverre netwerkpositie en aanwijzingen voor bedrijfsmatigheid met elkaar samenhangen. Tabel 2 laat zien dat degree centrality (het totaal aantal witwassers met wie een individuele witwasser geregistreerd contact heeft) positief samenhangt met het aantal verschillende zaken waarbij een witwasser betrokken is, het aantal verschillende contacten in die zaken en het aantal terugkerende criminele contacten (vermoedelijk klanten), terwijl er een negatieve correlatie bestaat tussen het aantal witwassers met wie een witwasser contact heeft en het percentage familiale relaties onder zijn of haar contacten. Deze laatste correlatie is echter niet significant. Deze resultaten bevestigen nog eens dat het aantal contacten dat een witwasser onderhoudt met andere witwassers eveneens gezien kan worden als een belangrijke indicatie voor de mate waarin de betreffende witwasser bedrijfsmatig handelt.

\section{Discussie}

In dit artikel is onderzocht of er in Nederland netwerken van professionele witwassers bestaan. Dat blijkt inderdaad het geval. Zelfs bij de strengste ondergrens, namelijk een daadwerkelijke vaststelling door een opsporingsambtenaar van contact tussen twee of meer witwassers, blijken 130 van de 236 onderzochte witwas- 
sers onderling contact te hebben. Inhoudelijk kunnen grofweg twee verschillende soorten netwerken worden onderscheiden. Het ene soort netwerk opereert in de vastgoedsector, terwijl de andere soort ondergrondse bankiers betreft.

Op zich is het bestaan van deze twee soorten netwerken niet vreemd. Het is bekend dat criminelen investeren in vastgoed (Van Duyne, 2003; Ferwerda e.a., 2007; Soudijn, 2018). Vastgoed kan in de eerste plaats worden gebruikt om in te wonen, of om er een legale of illegale onderneming in te vestigen. Vastgoed is echter voor criminelen - niet alleen in Nederland, maar ook in andere landen vooral interessant omdat de vastgoedsector vanwege een aantal factoren kwetsbaar is voor witwaspraktijken (Malm \& Bichler, 2013; Unger e.a., 2011). Net als voor gewone investeerders is de aantrekkingskracht van vastgoed gelegen in de hoge waarden hiervan, de mogelijkheid tot speculaties en het gebrek aan transparantie omtrent waardebepalingen. Daarbij komt voor criminelen ook nog eens de mogelijkheid om op talloze manieren het werkelijke eigendom van bezittingen te verbergen (Van Gestel e.a., 2008; Soudijn, 2018; Unger e.a., 2011). Dat in vastgoednetwerken notarissen, makelaars en adviseurs samenwerken is niet vreemd, want de wet schrijft voor dat bij iedere onroerendgoedtransactie een notaris betrokken moet zijn. Een notaris maakt namelijk de akte op en is verantwoordelijk voor de geldstromen. De (ex-)notarissen zelf hebben in onze onderzoeksdata overigens geen breed scala aan contacten. Zij houden het op contacten met een beperkt aantal andere witwassers.

Het bestaan van de tweede soort netwerken met ondergrondse bankiers is ook goed verklaarbaar. Ondergrondse bankiers zijn aantrekkelijk voor criminelen vanwege hun onofficiële karakter, de anonimiteit en efficiëntie, en de mogelijkheid die zij bieden om regelmatig forse geldbedragen ergens anders te laten uitbetalen (Kleemans e.a., 2002; Passas, 1999). Uit de literatuur (Van de Bunt \& Siegel, 2009; Maimbo, 2003; Passas, 1999) is bekend dat hawalabankiers vaak met familieleden samenwerken. De huidige analyses laten overigens zien dat dit alleen geldt voor de relaties tussen hawalabankiers en de overige verdachten in een zaak. Voor contacten tussen witwassers onderling verschillen hawalabankiers niet van overige witwassers.

Uit onze analyse blijkt verder dat witwassers die in netwerken opereren over het algemeen worden gekenmerkt door een hogere mate van bedrijfsmatigheid. Zij zijn namelijk bij meer zaken betrokken dan witwassers die individueel opereren, hebben meer verschillende contacten en hebben per saldo minder contacten met familie. Van hen kan dus gezegd worden dat zij een hoge mate van bedrijfsmatigheid laten zien.

De huidige data beslaan een periode van tien jaar. In die tien jaar wordt bijna de helft van de witwassers herhaaldelijk met dezelfde witwaspartner in verband gebracht, hetgeen continuïteit suggereert. Tegelijkertijd zien we dat continue contacten tussen witwassers zich in verreweg de meeste gevallen beperken tot tweetallen en dat van stabiele samenwerkingsverbanden tussen meerdere witwassers vooralsnog geen sprake lijkt.

Bij de huidige resultaten zijn ook enkele kanttekeningen te plaatsen. Zo ligt aan het onderzoek de assumptie ten grondslag dat geregistreerde contacten met overige verdachten in een zaak wijzen op een samenwerkingsrelatie, in die zin dat 
de witwasser crimineel geld witwast voor de overige verdachten in de betreffende zaak. Evenzo zijn contacten tussen witwassers onderling geïnterpreteerd als indicatief voor het bestaan van een zekere mate van samenwerking tussen twee of meer professionele witwassers. Hoewel deze assumptie gezien de aard van de data en het doel van het onderliggende opsporingsonderzoek gerechtvaardigd lijkt, is strikt genomen alleen het bestaan van het contact geregistreerd en niet de inhoud van dat contact. Ons onderzoek kan dus ook niets zeggen over de inhoudelijke samenwerking tussen professionele witwassers. Welke diensten nemen zij bijvoorbeeld bij elkaar af en hoe draagt dit bij aan het verhullen van de herkomst van het crimineel verdiende geld? Voor meer informatie over de eventuele samenwerking in witwastrajecten zal dossieronderzoek moeten worden gedaan. De constatering dat er veel relaties tussen witwassers onderling zijn, moet daarom als een eerste stap worden beschouwd.

Een tweede kanttekening is dat de opgebouwde netwerken volledig afhankelijk zijn van politieregistraties. Zo blijken de verdachten met wie de witwassers contact hebben hoofdzakelijk bij drugsdelicten betrokken. In die zin laten de resultaten dus zien dat er in Nederland netwerken van professionele witwassers van drugsgelden actief zijn. Mogelijk maken bijvoorbeeld fraudeurs gebruik van andersoortige professionele witwasnetwerken. Het is verder ook mogelijk dat er witwassers bestaan die dusdanig professioneel en geraffineerd opereren, dat zij nooit door de politie zijn opgemerkt. Daarnaast is het nog maar de vraag of de politie in alle zaken wel volledig heeft geregistreerd. Een verdachte drugshandelaar zou best contact met een witwasser kunnen hebben, maar als het opsporingsteam alleen op de kilo's is gefocust, bestaat het risico dat dit contact als niet relevant terzijde wordt geschoven (zie voor de politiepraktijk ook Huisman e.a., 2016; Princen, 2015; Soudijn, 2016). Dat betekent dat de professionele witwasnetwerken in Nederland in potentie groter en professionele witwassers bedrijfsmatiger kunnen zijn dan nu uit de politieregistraties is gebleken.

Een derde kanttekening is dat het ons onbekend is wie van de in de registraties genoemde personen uiteindelijk als verdachte van witwassen voor de rechter is gebracht. Niet ieder opsporingsonderzoek leidt namelijk tot een strafzaak en ook wordt niet iedere verdachte vervolgd. Dergelijke gegevens worden niet in de politieregistratiesystemen vastgelegd, maar bij het Openbaar Ministerie. Deze databron hebben wij niet bevraagd, omdat hier apart toestemming voor nodig is.

Ondanks deze kanttekeningen bij het onderzoek blijkt de constatering van de FATF dat er netwerken van professionele witwassers bestaan, ook voor Nederland opgeld te doen. Professionele witwassers en zeker professionele witwassers die met andere witwassers samenwerken, bieden bedrijfsmatig hun financiële diensten aan criminelen aan. Dat deze criminelen ook daadwerkelijk gebruik maken van deze diensten duidt erop dat professionele witwassers een essentiële rol vervullen in het voltooien van het crime script en daarmee een potentieel belangrijk aangrijpingspunt vormen voor interventie. De huidige onderzoeksresultaten onderbouwen dan ook het belang van aandacht voor witwassen in politieonderzoek naar (drugs)criminaliteit, temeer daar sommige witwassers over langere tijd actief blijken te zijn. Financieel opsporingsonderzoek en de recherche- 
capaciteit nodig om dit onderzoek goed uit te voeren zijn daarom een onmisbaar onderdeel in de bestrijding van georganiseerde criminaliteit.

\section{Literatuur}

Bichler, G. (2019). Understanding Criminal Networks. A Research Guide. Berkeley, CA: University of California Press.

Bijleveld, C.C.J.H. (2018). Methoden en technieken van onderzoek in de criminologie. Den Haag: Boom Lemma uitgevers.

Borgatti, S.P., Everett, M.G. \& Johnson, C.J. (2013). Analyzing Social Networks. Thousand Oaks, CA: Sage.

Bright, D.A., Greenhill, C., Ritter, A. \& Morselli, C. (2015). Networks within networks: using multiple link types to examine network structure and identify key actors in a drug trafficking operation. Global Crime, 16(3), 219-237.

Bunt, H., van de \& Siegel, D. (Eds.). (2009). Ondergronds bankieren in Nederland. Den Haag: Boom Juridische uitgevers.

Cornish, D.B. (1994). Crimes as scripts. In: D. Zahm \& P. Cromwell (eds.). Proceedings of the International Seminar on Environmental Criminology and Crime Analysis. Tallahassee, FL: Florida Statistical Analysis Center, 30-45.

Duyne, P.C. van (2003). Money laundering policy: fears and facts. In: P.C. van Duyne, K. von Lampe \& J.L. Newell (eds.). Criminal Finance and Organizing Crime in Europe. Nijmegen: Wolf Legal Publishers, 67-104.

EMCDDA/Europol. (2019). EU Drug Markets Report. Geraadpleegd op www.emcdda.europa.eu/publications/joint-publications/eu-drug-marketsreport-2019_en.

FATF. (2018). Professional Money Laundering. Paris: FATF. Geraadpleegd op www.fatfgafi.org/publications/methodandtrends/documents/professional-moneylaundering.html.

Ferwerda, H., Staring, R., Vries Robbé, E. de \& Bunt, J. van de (2007). Malafide activiteiten in de vastgoedsector. Een exploratief onderzoek naar aard, actoren en aanpak. Arnhem: Advies- en Onderzoeksgroep Beke.

Gestel, B. van, Kouwenberg, R.F., Verhoeven, M.A. \& Verkuylen, M.W. (2008). Vastgoed \& fout. Een analyse van twaalf strafrechtelijke opsporingsonderzoeken naar illegale en criminele praktijken in de woningsector. Den Haag: Boom Juridische uitgevers.

Gilmour, N. (2014). Understanding money laundering - a crime script approach. European Review of Organized Crime, 1(2), 35-56.

Huisman, S., Princen, M., Klerks, P. \& Kop, N. (2016). Handelen naar waarheid. Sterkte- en zwakteanalyse van de opsporing. Amsterdam: Politieacademie.

Kleemans, E.R., Brienen, M.E.I., Bunt, H.G. van de, m.m.v. Kouwenberg, R.F., Paulides, G. \& Barensen, J. (2002). Georganiseerde criminaliteit in Nederland. Tweede rapportage op basis van de WODC-monitor (Onderzoek en beleid 198). Den Haag: WODC/Boom Juridische uitgevers.

Knoop, J. van der \& Rollingswier, R. (2015). De bestrijding van witwassen: beschrijving en effectiviteit 2010-2013. Startversie monitor anti-witwasbeleid. Groningen/Den Haag: Decide/WODC.

Kruisbergen, E.W., Bunt, H.G. van de, Kleemans, E.R., m.m.v. Kouwenberg, R.F., Huisman, K., Meerts, C.A. e.a. (2012). Georganiseerde criminaliteit in Nederland. Vierde rapportage op basis van de Monitor Georganiseerde Misdaad (Onderzoek en beleid 306). Den Haag/ Rotterdam: WODC/Erasmus Universiteit Rotterdam. 
Kruisbergen, E.W., Roks, R.A., Kleemans, E.R., m.m.v. Kouwenberg, R.J., Knol, D., Nabi, S.S. e.a. (2019). Georganiseerde criminaliteit in Nederland: daders, verwevenheid en opsporing (Cahiers 2019-17). Den Haag: WODC.

Lacey, R. (1991). Little Man; Meyer Lansky and the Gangster Life. London: Random Century.

Leclerc, B. (2008). Crime scripts. In: R. Wortley \& M. Townsley (eds.). Environmental Criminology and Crime Analysis. London: Routledge, 119-141.

Maimbo, S.M. (2003). The Money Exchange Dealer of Kabul: A Study of the Hawala System in Afghanistan (Report). Washington, DC: World Bank.

Malm, A. \& Bichler, G. (2013). Using friends for money: the positional importance of money-launderers in organized crime. Trends in Organized Crime, 16(4), 365-381.

Middleton, David and Levi, Michael 2015. Let sleeping lawyers lie: organized crime, lawyers and the regulation of legal services. British Journal of Criminology, 55 (4), pp. 647-668.

Morselli, C. (2014). Crime and Networks. New York: Routledge.

Morselli, C., Giguere, C. (2006). Legitimate Strengths in Criminal Networks. Crime Law \& Social Change. 45, 185-200.

Obermayer, B. \& Obermaier, F. (2016). Panama Papers: het verhaal van de wereldwijde onthulling (W. Hansen, trans.). Amsterdam: Atlas Contact.

Passas, N. (1999). Informal Value Transfer Systems and Criminal Organizations; A Study into So-Called Underground Banking Networks. Den Haag: WODC.

Passas, N. (2003). Informal Value Transfer Systems, Terrorism and Money Laundering: A Report to the National Institute of Justice . Den Haag: WODC.

Princen, M. (2015). De gekooide recherche. Het ware verhaal achter de matige prestaties van de Nederlandse opsporing. Amsterdam: Prometheus Bert Bakker.

Rostami, A. \& Mondani, H. (2015). The complexity of crime network data: a case study of its consequences for crime control and the study of networks. PLOS ONE, 10(3), https://doi.org/10.1371/journal.pone.0119309.

Savona, E., Giommoni, L. \& Mancuso, M. (2014). Human trafficking for sexual exploitation in Italy. In: B. Leclerc \& R. Wortley (eds.). Cognition and Crime: Offender Decision Making and Script Analyses. London: Routledge, 140-163.

Siegel, D. \& Bunt, H. van de (2014). Underground banking in the Netherlands. In: S. Caneppele \& F. Calderoni (eds.). Organized Crime, Corruption and Crime Prevention. New York, NY: Springer, 251-261.

Soudijn, M.R.J. (2014). Using strangers for money: a discussion on money-launderers in organized crime. Trends in Organized Crime, 17(3), 199-217.

Soudijn, M.R.J. (2015). Hawala and money laundering: the potential use of red flags for persons offering hawala services. European Journal on Criminal Policy and Research, 21(2), 257-274.

Soudijn, M.R.J. (2016). Rechercheren een vorm van street-level bureaucracy. Proces, 95(6), 29-42.

Soudijn, M.R.J. (2017). Witwassen. Criminaliteitsbeeldanalyse 2016. Zoetermeer: Politie.

Soudijn, M.R.J. (2018). Using police reports to monitor money laundering developments. Continuity and change in 12 years of Dutch money laundering crime pattern analyses. European Journal on Criminal Policy and Research, 25(1), 83-97.

Unger, B., Ferwerda, J., Nelen, H. \& Ritzen, L. (2011). Money Laundering in the Real Estate Sector: Suspicious Properties. Cheltenham: Edward Elgar.

Unger, B., Ferwerda, J., Koetsier, I., Gjoleka, B., Saase, A. van, Slot, B. e.a. (2018). Aard en omvang van criminele bestedingen. Utrecht/Rotterdam/Amsterdam: Universiteit Utrecht/Ecorys/Vrije Universiteit Amsterdam. 